\title{
Response
}

\section{Third Invited Response: Broader Visions Encompassing Literacy, Learners, and Contexts}

\author{
Annemarie Sullivan Palincsar and Laura Klenk
}

I

N THEIR ARTICLE "Visions and

Revisions: A Special Education Perspective on the Whole Language Controversy," the authors describe two highly polarized approaches to reading instruction: whole language and direct instruction. This topic is of special importance and interest to us because, like the authors, we have been working in special education settings with teachers who have been trying to integrate elements of whole language instruction with more traditional direct instruction. We are regular witnesses to the tension these teachers experience as they seek to reconcile traditional approaches espoused in special education with more contemporary views (Klenk, in press; Palincsar \& Klenk, in press; Palincsar, Klenk, Anderman, Hric, \& Wilson, 1991). In addition, we have documented the responses of children who are caught in this tension, as expectations for their activity and performance vary quite dramatically from one task to another. That is, traditional skill-based activities typically assigned in the special education settings in which we are working require rote memory, are clearly defined in terms of their beginning and ending points, begin with the teacher, and are presented in fairly linear, predictable ways. The tasks we have introduced, such as responding to literature and telling or writing original stories, place different cognitive demands on the children, are ambiguous with regard to their beginnings and endings, are informed in large measure by the entering activity of the learner, and proceed in a less linear way because we do not assume that the "lower order" skills of reading (decoding) and writing (handwriting, spelling) are prerequisite to making real use of reading of writing in everyday and academic activity.

We commend Gersten and Dimino for two reasons. First, they have moved the debate along by extending their analysis beyond the "whole word versus phonics" issue that has received a great deal of attention in special education literature (Fisher, 1985; Foorman \& Liberman, 1989; Groff, 1977; Vellutino, 1991; Vellutino \& Scanlon, 1986). We also commend the authors for their invitation to members of the opposing positions to engage in dialogue, a worthwhile effort in light of the continued zeal with which the controversy rages, fueled by intense political, psychological, and methodological ideologies (Edelsky, 1990).

We do not actually agree with the authors' characterization of whole language. Whole language represents a perspective on language instruction; it does not describe an instructional procedure. It is not possible to make the sweeping generalizations concerning whole language that are framed in "Visions and Revisions." In fact, although teachers who assume a whole language perspective are more likely to engage in certain instructional practices, such as the use of trade-book literature and dialogue journals, there is considerable variability within those instructional procedures (Turner, 1991). Nor do we believe that reductionism is the sole flaw inherent in direct instruction. However, we do not believe that the authors would wish to mire this discussion in definitions, and we do not wish to spend our precious space quibbling; instead, we would like to urge that the dialogue broaden in scope to consider literacy (as opposed to simply reading) and shift to examine more overarching issues, such as the purposes and contexts of literacy instruction-especially for children who are experiencing difficulty with the development of reading and writing. We believe that these are highly interrelated issues that will provide a useful framework for examining instructional practice. In addition, we wish to identify three perspectives that 
may enhance our exploration of these issues: cognitive-science, socio-cultural, and developmental. We will conclude with illustrations of the ways in which these perspectives, particularly the developmental perspective, are influencing our collaborative work in special education classrooms.

\section{Examining Literacy and Literacy Instruction in Special Education}

What counts as literacy is, of course, debatable; yet we need to examine the extent to which, as a community of special educators and researchers, we have a shared definition of literacy. An evolving view of literacy that has been influenced by the field of cognitive science suggests that literacy is not simply reading and writing but is also reasoning and problem solving with print. This view has significant implications when determining the goals of instruction as well as the means by which we evaluate the scope of our problems and the success of our efforts at remediation. From this broader view we are driven to ask questions about the experiences our children have with literacy and the conceptions of reading and writing that obtain from these experiences. We are pressed to ask questions about the breadth of uses to which our students apply their literacy learning; and we are prodded to think about ways in which multiple uses of literacy (i.e., literacy for the purpose of informing, communicating, recreating, and creating) can be conceived of as a repertoire and not as a developmental sequence (see Wells, 1990). This last charge is a particularly challenging one-how can special education students who experience tremendous difficulties with the performative aspects of reading and writing still experience the satisfaction and outcomes associ- ated with a repertoire of literacy skills? A socio-cultural perspective provides a portion of the answer.

From a socio-cultural perspective, reasoning and problem solving with print are viewed as socially situated activities (Cook-Gumpertz, 1986; Scribner \& Cole, 1981). Children become literate, not through their interactions with artifacts such as text or computer screens, but rather through their participation in socially organized activities with written language. We have been particularly influenced by this perspective as we attempt to influence the contexts in which special education students develop literacy. From this perspective instructional opportunities are provided in which learning occurs in social and interactive ways, such as through the use of paired readings and reader's chair, peer-writing conferences, and author's chair (DuCharme, Earl, \& Poplin, 1989; Englert \& Palincsar, 1991). From this perspective, teachers are viewed as assisting performance (Tharpe \& Gallimore, 1989), supporting children's attempts to use literacy and guiding them in more refined uses.

There is a final perspective that has guided our efforts and to which we would like to call the attention of the special education community: a developmental perspective, as suggested by research on emergent literacy. Vygotsky (1978) observed, "Make believe play, drawing, and writing can be viewed as different moments in an essentially unified process of written language development" (p. 115). From an emergent literacy perspective (see Mason \& Allen, 1986; Strickland, 1990; Sulzby, 1986; Teale, 1987; Teale \& Sulzby, 1986), a broad array of responses on the part of the child is acknowledged as literate activity, such that the child is admitted into the literate community long before he or she is consistently applying the conventions of print.

\section{Illustrations}

We would like now to illustrate the ways in which the cognitive science, socio-cultural, and developmental perspectives have been influencing our work with special education teachers in redesigning the curriculum and content of literacy instruction in self-contained classrooms for primary children with learning disabilities. It is important that the reader understand that we are not putting forth these illustrations to suggest that we now have "the answers" as informed by the three perspectives that we have presented. Rather, our purpose is to illustrate how these perspectives have guided our attempts, what issues have emerged from these attempts, and what questions still loom large for us. It is our hope that these illustrations will provide "grist" for the dialogue that Gersten and Dimino encourage. (Note: In each example, "teacher" refers to the second author, and the children are identified by pseudonyms.)

Jeremy. At the start of his second-grade year, Jeremy was age 7.6. He had difficulty remembering the names of letters; he relied on saying the alphabet sequence while following a printed wall chart to identify letters he wished to use in writing. Jeremy did not have stable sound-letter associations, despite daily instruction in phonics and handwriting. Although he had a stable concept of words as visual units and was able to invent spellings using one sound per syllable, Jeremy was not yet decoding from either sight words or phonetic analysis. In mid-November, Jeremy was writing in his "News Book," a daily journal through which the children were encouraged to use writing for communicative and recreational purposes. Jeremy had frequently lamented the fact that several of his favorite classmates had moved on to another 
school, and this had been the theme of his conversations and news writing for several days. On this occasion, Jeremy began by writing the following: I MS MI F NF ("I miss my other friends") (see Figure 1). Jeremy encountered a problem when he tried to read the sentence from memory to retrieve his train of thought. He tried to match the words he remembered writing, but because the letters were strung together without spaces, he could not match his writing to the message he intended to convey. He tried starting over, pointing to the string of letters while saying, "I miss my other friends."

The teacher responded by pointing to the letters Jeremy had written for each word as Jeremy repeated the sentence. Then, before Jeremy continued writing, the teacher explained that writers use spaces between words to help them remember what they have written. She opened a book on Jeremy's desk and pointed out the spaces between the words. Jeremy remarked that he already knew about "those holes," and he found the handwriting sheet on which he had copied a poem from the chalkboard earlier that morning. He pointed to the spaces between the words on that sheet, to show the teacher that he had used spacing in that context. The teacher reminded Jeremy that he could use his finger to help separate the words, and Jeremy acknowledged that he had also done this before.

However, as Jeremy continued writing his own story, the teacher realized that he could not tell where one word ended and another began. (This may have been due in part to the intense concentration needed for making the letter-sound associations.) To assist Jeremy, the teacher encouraged him to listen for the sounds in the word he was writing, then reminded him, "New word," when

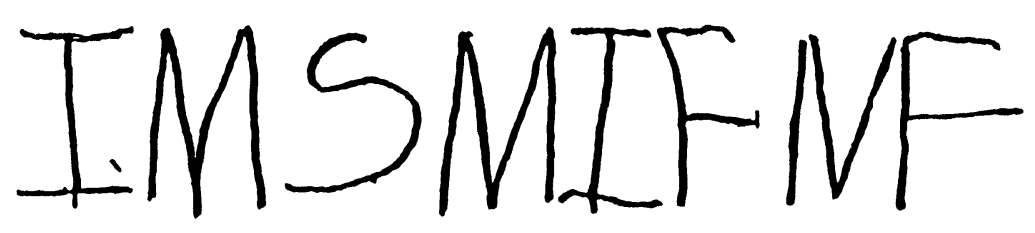

Figure 1. "I miss my other friends."
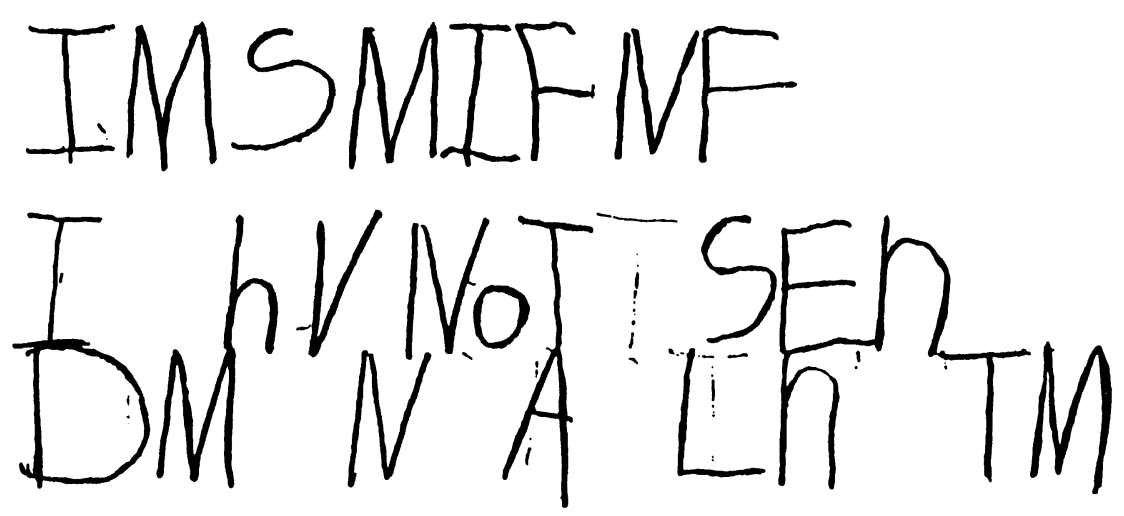

Figure 2. "I miss my other friends. I have not seen them in a long time."

it was clear that he was ready to proceed with another word. Figure 2 shows the completed journal entry, to which is added, I hV NoT SEn DM N A LN TM ("I have not seen them in a long time").

After this session, Jeremy quickly gained both confidence and skill in separating words. However, he still seeks reassurance from the teacher, asking, "New word?" when he is ready to leave a space. Figure 3 shows a more recent example of Jeremy's writing, produced a week before his eighth birthday. In this story, Jeremy reported an incident he had witnessed from the school bus earlier that morning: A kreVl $\mathrm{N}$ The yoTTr D To TK TRD T PLP T T ("A car fell in the water. The tow truck tried to pull it out').

We use the story of Jeremy to make several points. Despite the fact that Jeremy had been using "spacing" in his daily copying activity for over a year of primary schooling, it was not until he tried to read his own composition that he began to understand the significance of spacing as a print convention. Furthermore, Jeremy's successful experiences using literacy to convey his own ideas and to express, in the one case his sadness over being separated from his friends, and in the other, the interest engendered by the unusual event he witnessed on his way to school, were mediated by the assistance of the teacher, who, for example, prompted him to listen for the sounds in the words he was writing, indicated when he was beginning a new word, and held his thoughts in memory so Jeremy could concentrate on the actual writing.

Ricky. Ricky, age 7.0, is a classmate of Jeremy's. Those who are not familiar with Ricky find his speech nearly unintelligible due to a severe speech impairment. Although he is able to dis- 
criminate between sounds, he has great difficulty making accurate sound-letter associations. Still, for almost 2 years Ricky has shown a great desire to write. When the second author first began observing in his classroom, Ricky often took her notebook and pen from her and filled page after page with cursive-like loops.

When he was given his own News Book, Ricky continued writing in cursive-like scribbles, but gradually added pseudo-letter forms, strings of random letters, and words copied from environmental print (e.g., classroom posters, signs, lists, writing on the chalkboard, etc.). For over a year, Ricky did not read original stories from his emergent writing. Instead, he listened to his classmates read their emergent stories and incorporated their ideas into his own emergent readings.

Rather than focusing on the forms of writing Ricky used, the teacher began to probe him for more personal information with such prompts as, "What did you do after school yesterday?" After finding a topic Ricky was willing to talk about, the teacher would ask, "Is that what you want to write about today?" When Ricky agreed to a topic, the teacher would prompt him to write by asking, "How are you going to start?" or, "What will you say first?" After soliciting original statements from Ricky, the teacher would pronounce the words slowly, as if giving dictation. When Ricky seemed comfortable with the notion of writing original stories, the teacher began prompting him to listen for the sounds in the words as he wrote. For several weeks, Ricky continued his cursive-like scribble, but he gradually began to listen for sounds, which he would represent with random letters. Soon the teacher began to suggest specific letters. One day Ricky wanted to write "grandma," but he got stuck after the initial consonant sound. The teacher modeled the next letter-sound association

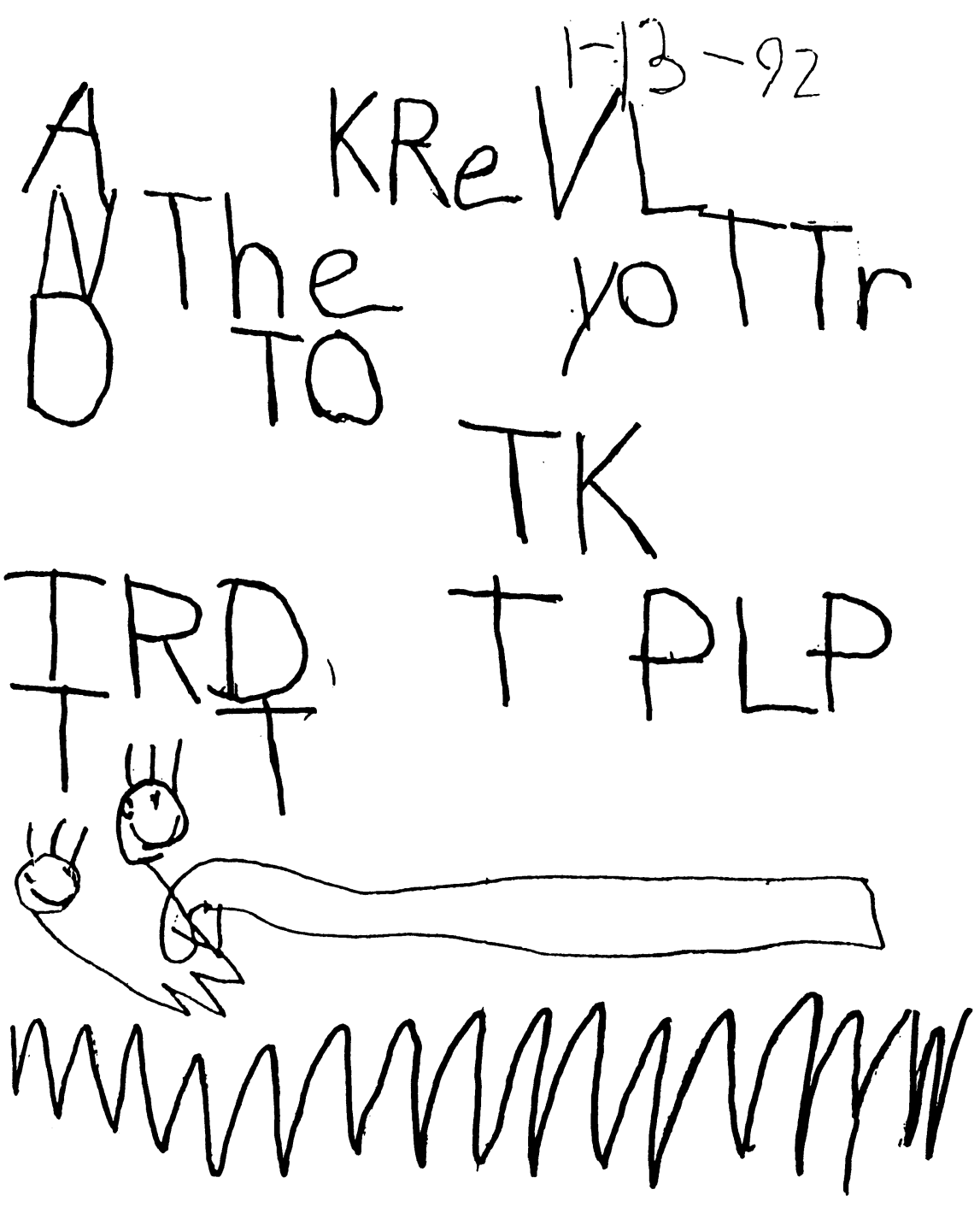

Figure 3. "A car fell in the water. The tow truck tried to pull it out."

(based on Ricky's pronunciation): "Grandma - $/ \mathrm{m} / / \mathrm{m} /$ - I hear an ' $m$ ' in the middle of grandma."

Ricky now looks forward to discussing and choosing his own topics for writing. He forges ahead with invented spellings, which are becoming more and more accurate. Ricky also became interested in spacing between his words after listening to Jeremy's conversations with teachers during writing time. Figure 4 shows a current entry in Ricky's News Book: I t p 6 Ioht $\mathrm{m} \mathrm{K} \mathrm{N} \mathrm{I} \mathrm{O} \mathrm{K} \mathrm{a} \mathrm{B} \mathrm{B}$ ("I get up at 6 . I put my clothes on. I always take a bubble bath").

In Ricky's case, the teacher was attentive to his interest in writing but did not immediately discourage his use of cursive-like scribble. After Ricky began using letters and copying words he recognized, the teacher prompted him to write original stories, helping him sound out words and make letter-sound associations. These activities fatigued Ricky rather quickly at first, and he would often revert to using cursive-like scribbles after writing a few letters. This was not discouraged, either. However, as Ricky showed greater tolerance for writing, the teacher gradually led him to greater involvement with conventional aspects of print.

Katrice. The final example comes from a student in another self-contained special education classroom. Katrice, age 8 , had 


\section{土†

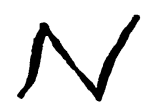 \\ J

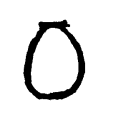

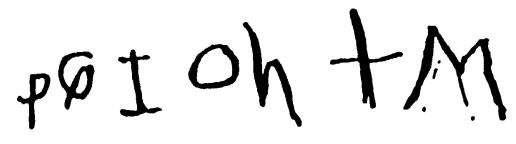

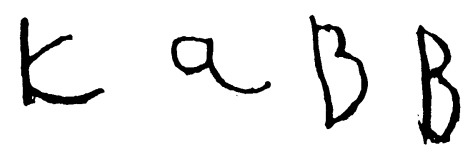

Figure 4. "I get up at 6 . I put my clothes on. I always take a bubble bath."

repeated kindergarten and was then assigned to the special education class. She spent her firstgrade year and her second-grade year in this class, where she received reading instruction from a district-mandated phonics program (Explode the Code) and from a basal curriculum. Like Jeremy, Katrice exhibited almost no phonemic awareness: She was not able to segment words into syllables or sounds, nor could she blend a string of sounds into a word. However, she enjoyed performing emergent readings, or reenactments, of story books.

When Katrice read from her favorite stories, she paid no attention to the print in these trade books. She did not point to the words, and her eyes remained on the illustrations. However, when asked to read from the preprimers used in her classroom, Katrice tracked the print with her eyes and read verbatim from portions she had memorized in class. (She was not able to identify individual words when asked.) One day, the teacher asked Katrice to read a new trade book-one she had never seen before. This time, Katrice protested and said that she could not read. The teacher suggested that Katrice read it "her own way," just like she read her Clifford books and other favorite stories. After a lengthy hesitation, Katrice took the book and described the pictures in the new story. Later, the teacher read the story to Katrice.

Katrice's discomfort with reading an unfamiliar story alerted the teacher to the realization that Katrice was very much aware that her own reading was not like that of grown-ups. The next time Katrice protested over reading, the teacher asked if she wanted to read in "grown-up" instead of in "kid reading." Katrice agreed. The teacher told Katrice, "Show me where you will start." Katrice pointed to the first line of print in the book and, with her eyes on the text, began to recall the story from memory. After reading one or two lines, Katrice realized that she had forgotten the text and stopped reading. At this point, the teacher supplied the next word and Katrice continued. The reading proceeded in this fashion, with the teacher supplying most of the words but pausing when she thought that Katrice could finish a phrase or sentence from memory or from the illustrations.

Over time, Katrice and the teacher read a number of stories in this manner, with Katrice gradually showing increased attention to the print. A very similar process was documented for Katrice's writing development (see Klenk, in press). When Katrice was especially confident with a story, she would take over responsibility for the reading. When she was hesitant to read, or became fatigued, the teacher would ask Katrice to choose the pages she wished to read (she often chose pages with the least amount of print). By supplying unknown or forgotten text, and by allowing Katrice to choose the portions of stories she wished to read, the teacher ensured that Katrice could feel a measure of control and success with the reading task.

\section{Implication for Research}

Our quest to incorporate a socio-historical perspective and emergent literacy theory into our work with special education teachers and students has demanded a concurrent search for appropriate methodology with which to conduct our research. This search has led us to questions, with Danziger (1990), the traditionally narrow conception of the relationship between theory and model. In our experimentation, we seek not only to test a theory, but also to construct a working model, to demonstrate a theory in action. Our working model is one of experimentation, and it constantly changes as students and teachers learn to identify their own needs and interests, and as they learn to trust us enough to share these with us.

For now, we are finding case studies of individual students to be highly informative, and we hope that additional case studies will be forthcoming from other research projects. Simultaneously, we are conducting ethnographies of special education classrooms to determine which aspects of particular cultures foster or inhibit multiple uses of literacy.

\section{Conclusion}

Gersten and Dimino speak in their title of visions and revisions. A final illustration from Jeremy 
(introduced earlier) will serve to highlight an important lesson we have learned from our work, a lesson that has led us to yet another vision. Jeremy was writing in his News Book one day, trying to spell a word that contained the $m$ sound. His eyes scanned the alphabet chart on the front wall of the classroom, but he could not seem to match the sound to a letter. The teacher who was observing Jeremy suggest that he look for the monkey on the chart. When he spied the monkey with the letter $m$ printed beneath it, Jeremy's response was not to name the letter. Instead, he called out, "Marcus$m$ like in Marcus!' Marcus was a former classmate and good friend of Jeremy's from the previous school year.

After several years of failing to "break the code" in which he had received instruction, Jeremy was creating his own code, making associations that were meaningful to him, in the context of composing an original story. Jeremy, Ricky, Katrice, and many other children in similar classrooms have shown us that they have the determination to create their own personal, meaningful codes that they can use to achieve competence in reading and writing. Helping children create their own codes, and working with teachers as they struggle to help children in this process of creation, is part of our own vision.

Annemarie Sullivan Palincsar
is associate professor in educa-
tional studies at the University
of Michigan. A former special
educator, she prepares teachers
to work with diverse groups of
students. She conducts research
on the development and instruc-
tion of literacy with students
with learning disabilities and
on peer collaboration in scien-
tific problem-solving activity. She
completed ber PhD at the Univer-

Annemarie Sullivan Palincsar is associate professor in educato work with diverse groups of students. She conducts research tion of literacy with students with learning disabilities and on peer collaboration in sciencompleted her PbD at the Univer- sity of Illinois-Champaign. Laura Klenk is a doctoral student in educational studies at the University of Michigan. She received ber $M A$ in curriculum and instruction from the University of Wyoming. She taught children in elementary and special education classrooms for 9 years. Her research interests include emergent literacy, special education, and teacher preparation. Address: Annemarie Sullivan Palincsar, University of Michigan, 1360 F Scbool of Education Building, Ann Arbor, MI 48109.

\section{Authors' Note}

The illustrations reported in this article were drawn from a program of research funded by a grant (No. H023C90076) awarded from The Office of Special Education Programs to the first author and Carol Sue Englert (co-principal investigator), Taffy Raphael, and James Gavelek.

\section{References}

Cook-Gumpertz, J. (1986). The social construction of literacy. Cambridge, England: Cambridge University Press.

Danziger, K. (1990). Constructing the subject. Cambridge, England: Cambridge University Press.

DuCharme, C., Earl, J., \& Poplin, M.S. (1989). The author model: The constructivist view of the writing process. Learning Disability Quarterly, 12, 237-242.

Edelsky, C. (1990). Whose agenda is this anyway? A response to McKenna, Robinson, and Miller. Educational Researcher, 19(8), 7-11.

Englert, C.S., \& Palincsar, A.S. (1991). Reconsidering instructional research in literacy from a sociocultural perspective. Learning Disabilities Research and Practice, 6, 225-230.

Fisher, R.I. (1985). Visual and motor preferences may determine reading approach. Journal of Human Behavior and Learning, 2(1), 13-18.

Foorman, B.R., \& Liberman, D. (1989). Visual and phonological processing of words: A comparison of good and poor learners. Journal of Learning Disabilities, 22, 349-355.

Groff, P. (1977). The new anti-phonics. Elementary School Journal, 77, 323-332.

Klenk, L. (in press). Case study in reading disability: An emergent literacy perspective. Journal of Learning Disabilities.

Mason, J.M., \& Allen, J. (1986). A review of emergent literacy with implications for research and practice in reading. In E.Z. Rothkopf (Ed.), Review of research in education (Vol. 13, pp. 27-43). Washington, DC: American Educational Research Association.

Palincsar, A.S., \& Klenk, L. (in press). Fostering literacy learning in supportive contexts. Journal of Learning Disabilities.

Palincsar, A.S., Klenk, L., Anderman, E., Hric, K., \& Wilson, A. (1991, December). Fostering intentionality in writing through alternative discourse practices with students identified as learning disabled. Paper presented at the annual meeting of the National Reading Conference, Palm Springs, CA.

Scribner, S., \& Cole, M. (1981). The psychology of literacy. Cambridge, MA: Harvard University Press.

Strickland, D.S. (1990). Emergent literacy: How young children learn to read and write. Educational Leadership, 47(7), 18-23.

Sulzby, E. (1986). Writing and reading: Signs of oral and written language organization in the young child. In W.H. Teale \& E. Sulzby (Eds.), Emergent literacy: Understanding reading and writing (pp. 50-89). Norwood, NJ: Ablex.

Teale, W.H. (1987). Emergent literacy: Reading and writing development in early childhood. In J.E. Readence \& R.S. Baldwin (Eds.), Thirtysixtb Yearbook of the National Reading Conference (pp. 45-74). Rochester, NY: National Reading Conference.

Teale, W.H. \& Sulzby, E. (Eds.). (1986). Emergent literacy: Understanding reading and writing. Norwood, NJ: Ablex.

Tharpe, R., \& Gallimore, R. (1989). Rousing minds to life. New York: Cambridge University Press. 
Turner, J. (1991, December). The influence of classroom context on first graders' motivation for literacy. Paper presented at the National Reading Conference, Palm Springs, CA.

Velluntino, F.R. (1991). Introduction to three studies on reading acquisition: Convergent findings on theoretical foundations of codeoriented versus whole-language approaches to reading instruction. Journal of Educational Psychology, 83, 437-443.

Velluntino, F.R., \& Scanlon, D.M (1986). Experimental evidence for the effects of instructional bias on word identification.
Exceptional Children, 53, 145-155.

Vygotsky, L.S. (1978). Mind in society: The development of bigher psychological processes. Cambridge, MA: Harvard University Press.

Wells, G. (1990). Talk about text: Where literacy is learned and taught. Curriculum Inquiry, 21, 369-405.

(continued from p. 16)

Davis, R.B. (1971-72). The structure of mathematics and the structure of cognitive development. Journal of Children's Mathematical Behavior, 1, 71-97.

Hutson, B. (1987). Literacy at school and literacy at work. In D. Bloome (Ed.), Literacy and schooling (pp. 225-253). Norwood, NJ: Ablex.

Kitchener, R.F. (1991, May). Semantic naturalism: The problem of meaning and naturalistic psychology. Paper presented at the 21 st annual symposium of the Jean Piaget Society, Montreal, Quebec, Canada.
Reid, D.K. (1991). The cognitive curriculum. In D.K. Reid, W.H. Hresko, \& H.L. Swanson (Eds.), A cognitive approach to learning disabilities (pp. 297-315). Austin, TX: PRO-ED

Reid, D.K. (1992). Learning disorders and the flavors of cognitive science. In L. Meltzer (Ed.), Strategy assessment and instruction for students with learning disabilities: From theory to practice (pp. 15-47). Austin, TX: PRO-ED.

Resnick, L.B. (1989). Introductions. In L.B. Resnick (Ed.), Knowing, learning, and instruction (pp 1-24). Hillsdale, NJ: Erlbaum.

Rogoff, B. (1990). Apprenticeship in thinking: Cognitive development in social context. New York: Oxford University Press.

Stephens, D. (1991). Research on whole language: Support for a new curriculum. Katonah, NY: Richard C. Owen.

Wertsch, J.V. (1991). Voices of the mind: A sociocultural approach to mediated action. Cambridge, MA: Harvard University Press.

(continued from p. 18)

of Illinois and the project coordinator for the Standards Project for English Language Arts. Marcy Stein is an assistant professor at the University of Washington, Tacoma, who specializes in the education of at-risk and mildly disabled students. Address: Jean Osborn, 174 Children's Research
Center, 51 Getty Dr., Champaign, IL 61820 .

\section{References}

Adams, M.J. (1990). Beginning to read: Thinking and learning about print. Cambridge, MA: MIT Press. Anderson, R.C., Hiebert, E.H., Scott, J.A., \& Wilkinson, I.A.G. (1985).
Becoming a nation of readers: The report of the Commission on Reading. Champaign, IL: Center for the Study of Reading.

Routman, R. (1988). Transitions: From literature to literacy. Portsmouth, NH: Heinemann.

Smith, F. (1992, February). Learning to read: The never-ending debate. Phi Delta Kappan, 442-431. 